\title{
A group of transport amphorae from the territorium of Ceramus: typological observations
}

\author{
Abuzer Kızıl and Asil Yaman
}

\section{(2) OpenEdition}

1 Journals

\section{Electronic version}

URL: http://journals.openedition.org/anatoliaantiqua/435

DOI: 10.4000/anatoliaantiqua.435

\section{Publisher}

IFEA

\section{Printed version}

Date of publication: 1 May 2017

Number of pages: 17-32

ISBN: 978-2-36245-066-2

ISSN: 1018-1946

\section{Electronic reference}

Abuzer Kızll and Asil Yaman, « A group of transport amphorae from the territorium of Ceramus:

typological observations », Anatolia Antiqua [Online], XXV | 2017, Online since 01 May 2019, connection on 19 December 2020. URL : http://journals.openedition.org/anatoliaantiqua/435; DOI : https:// doi.org/10.4000/anatoliaantiqua.435 


\section{ANATOLIA ANTIQUA ESKI ANADOLU}

\section{XXV}

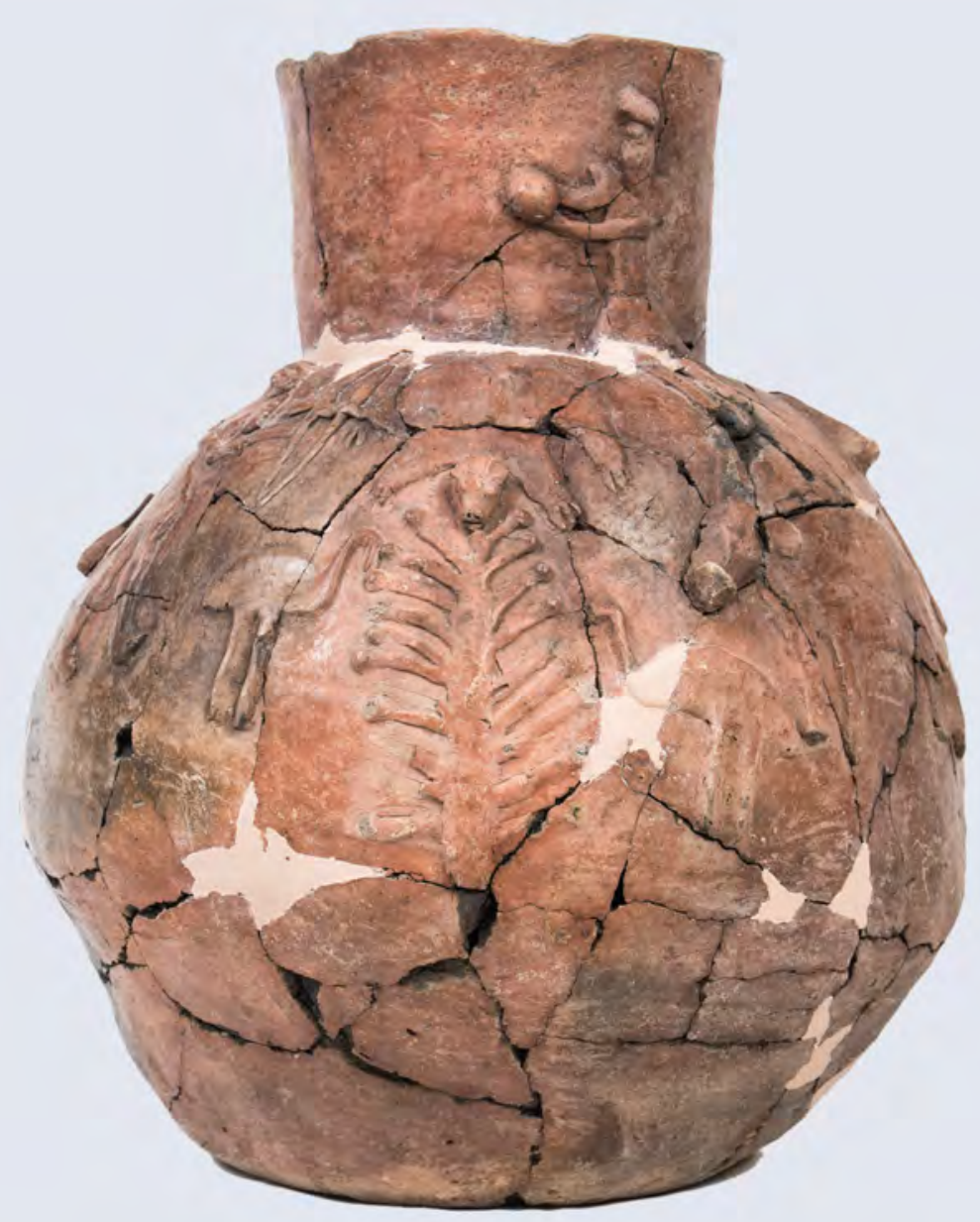

INSTITUT FRANÇAIS D'ETUDES ANATOLIENNES GEORGES-DUMEZIL

CNRS USR 3131

DE BOCCARD 


\section{TABLE DES MATIERES}

N. Pınar ÖZGÜNER et Geoffrey D. SUMMERS

The Çevre Kale Fortress and the outer enclosure on the Karacadağ at Yaraşl1

Abuzer KIZIL et Asil YAMAN

A group of transport amphorae from the territorium of Ceramus: Typological observations

Tülin TAN

The hellenistic tumulus of Eşenköy in NW Turkey

Emre TAŞTEMÜR

Glass pendants in Tekirdağ and Edirne Museums

Liviu Mihail IANCU

Self-mutilation, multiculturalism and hybridity. Herodotos on the Karians in Egypt (Hdt. 2.61.2) .....

\section{CHRONIQUES DES TRAVAUX ARCHEOLOGIQUES EN TURQUIE 2016}

Erhan BIÇAKÇI, Martin GODON et Ali Metin BÜYÜKKARAKAYA, Korhan ERTURAÇ, Catherine KUZUCUOĞLU, Yasin Gökhan ÇAKAN, Alice VINET

Les fouilles de Tepecik-Çiftlik et les activités du programme Melendiz préhistorique, campagne 2016

Çiğdem MANER

Preliminary report on the forth season of the Konya-Ereğli Survey (KEYAR) 2016

Sami PATACI et Ergün LAFLI

Field surveys in Ardahan in 2016

Erkan KONYAR, Bülent GENÇ, Can AVCI et Armağan TAN

The Van Tušpa Excavations 2015-2016

Martin SEYER, Alexandra DOLEA, Kathrin KUGLER, Helmut BRÜCKNER et Friederike STOCK The excavation at Limyra/Lycia 2016: Preliminary report

Abuzer KIZIL, Koray KONUK, Sönmez ALEMDAR, Laurent CAPDETREY, Raymond DESCAT, Didier LAROCHE, Enora LE QUERE, Francis PROST et Baptiste VERGNAUD

Eurômos : rapport préliminaire sur les travaux réalisés en 2016

O. HENRY et D. LÖWENBORG, Fr. MARCHAND-BEAULIEU, G. TUCKER, A. FREJMAN,

A. LAMESA, Chr. BOST, B. VERGNAUD, I. STOJANOVITC, N. CARLESS-UNWINN,

N. SCHIBILLE, Ö.D. ÇAKMAKLI, E. ANDERSSON

Labraunda 2016 


\section{A GROUP OF TRANSPORT AMPHORAE FROM THE TERRITORIUM OF CERAMUS: TYPOLOGICAL OBSERVATIONS}

Ceramus is a coastal settlement located along with the northern part of the Ceramus gulf, to which it gave its name, within the border of the Caria region in the ancient periods.

The city located in the Ören town of Muğla province, $40 \mathrm{~km}$ far from Milas (Pl. 1: Fig. 1). During the archaeological surveys at the settlement in 2012, detailed researches were particularly made about public buildings like theater, bathhouse and temple of the city, and city walls, waterways and the conservation situations of the necropolis ${ }^{1}$. In addition to those endeavors, technical documentation, and researches of newly discovered architectural components were simultaneously carried out.

Aforementioned artifacts were put under protection and delivered to the Milas Museum. Among the artifacts put under protection, 13 amphoras taken out of sea were located within and nearby the Alnata $\mathrm{Hotel}^{2}$, which is situated on the western side of the Ören coast (Pl. 1: Fig. 2) 3 $^{3}$. As the probable production centers of amphoras were designated with reference to the typological characteristics of amphoras, date suggestions were presented by making analogical analysis, and forms were aligned in accordance with these suggestions ${ }^{4}$. The amphoras, which present a wide range from Tyrrhenian coasts in Italy, Levant in the Eastern Mediterranean to the Eastern Aegean settlements, reflect that Ceramus had effective overseas commercial relations during the Ancient periods.

\section{TYPE 1}

As a result of style critique studies, we made on amphoras that constitute our study subject, Type 1 represented by one sample was identified to be the Samian Amphora.

Samos Island is accepted as a center producing olive oil in the South Ionia with Miletos in the opposite coast and exporting its products mostly to the western Mediterranean settlements, particularly the Eastern Aegean coasts, between $7^{\text {th }}$ century B.C. and $4^{\text {th }}$ century A.D. ${ }^{5}$. A workshop producing amphora has yet not been identified on the island.

The existence of the production is proved by the amphoras portrayed with the olive branch on the Samos coins dated $5^{\text {th }}$ century B.C. and those amphora handles stamped with $\mathrm{SA}^{6}$. Zeest is the first person, who associated the island with amphora production, in literature ${ }^{7}$. The most comprehensive and well-accepted study on this issue was made by V. Grace in $1971^{8}$. The earliest examples in terms of the form

*) Assistant Prof. Dr. Abuzer Kızıl, Muğla Sitkı Koçman University, Faculty of Letters and Humanities, Department of Archaeology, 48000 Kötekli-Muğla, Turkey, akizil@mu.edu.tr

Research Scholar Asil Yaman, University of Pennsylvania, Museum of Archaeology and Anthropology, Philadelphia, USA, ayaman@upenn.edu

1) For the survey explorations in and nearby Ceramus, see Kiz1l 2008: 357-374; Kız1l and Öztekin 2009: 293-310; 2010: 359-384; 2011: 401-416; Kiz1l 2012: 423-438.

2) It was not clearly reached from exactly which point of the sea such amphoras, which were probably taken out by fishermen, were taken out.

3) Survey explorations in the region conducted by Assistant Prof. Dr. Abuzer Kızıl, were supported by Muğla Sitkı Koçman University, within the scope of the Scientific Research Project named "Keramos (Ören) Antik Kenti'ndeki Taşınır ve Taşınmaz Kültür Varlıklarını Belgeleme Çalışmaları (2011/34)".

4) We thank Assistant Prof. Dr. Erkan Dündar for his suggestions and support during the typological researches, and the research assistant Taylan Doğan for dealing with technical documentations like drawings and taking photos of the amphoras. 325.

5) Grace 1971: 74; Doğer 1991: 14; Dupont 1998: 165; Şenol 2003: 7; Greene et al. 2011: 63; Sezgin 2012: 175-199; Aslan 2015:

6) Grace 1971: 52; Mattingly 1981: 81.

7) Zeest 1960: Pl. I.3; Dupont 1998: 164.

8) Grace 1971: 52. 
are identified as outflow rim, short-necked, arced connecting to out of shoulder from the middle of the neck, vertical short handles, and spherical body, shallow hollowed pedestal and with narrow ring base. Molding on the shoulder pass of neck takes part as a characteristic feature. It is mentioned that the form lengthened and thinned in $5^{\text {th }}$ century B.C. The handles diverged from being arced based on lengthening, and had ovoidal appearances sliding to the middle of the body from the shoulder level, which is the widest part of the body. The amphoras having aforementioned features are called as "late type" by P. Dupont".

The sample discovered on the Ceramus coast is rounded in the end, outflow lipped and short necked. It has vertical and thick handles connecting to shoulder from the upper part of the neck. Having an ovoidal structure, the body also has a carved ring pedestal inside (Pl. 2: 1). The aforementioned sample should be dated back to the second half of $5^{\text {th }}$ century for the reasons like an ovoidal structure of the form more than spherical, the narrowness of pedestal, handles having baton characteristics more than an $\operatorname{arch}^{10}$.

\section{TYPE 2}

It is possible to include Type 2, which is identified in surveys and represented with a sample, in the amphoras classification known as "mushroom type" in literature, based on the significant formal situation in its mouth structure.

Their predecessors were first found in the northern part of the Black Sea by I.B. Zeest and named as Solocha $\mathrm{I}^{11}$. Zeest identified seven different sub-categories over the samples found in the region ${ }^{12}$.
The earliest prototypes of the form were identified in a closed deposit, and were dated to the third quarter of $5^{\text {th }}$ century B.C. ${ }^{13}$. M. Lawall identified eight sub-categories of them based on the foundlings of Athens ${ }^{14}$. The successors of mushroom type amphoras, which were manufactured by many different centers in the Mainland Greece ${ }^{15}$, the Aegean islands ${ }^{16}$ and the Southeast Aegean coasts ${ }^{17}$ by becoming widespread during $4^{\text {th }}$ century B.C. ${ }^{18}$, were used during the Hellenistic period ${ }^{19}$. The amphoras, which were thought to be carrying wine, spread over the Aegean coasts, the Black Sea, Egypt and the Levant settlements during the Hellenistic period ${ }^{20}$.

The sample found in Ceramus is outwardly sloping and drooping brimmed, cylindrical neck, having oval-sectioned handles combining with the shoulder from just below the rim, a body widening to shoulders and narrowing to pedestal. Its pedestal was found broken (Pl. 2: 2). Generally, the form is easily identifiable with its significant outstretched triangle-mouthed structure and spherical body in terms of typology. In the Ceramus sample, it is observed that the body gets narrower from shoulders to pedestal in spandrel form. Although it poses a difficulty as the pedestal is broken, the form should be dated between the second half and the end of $4^{\text {th }}$ century B.C. as a result of the analogical evaluation made with similar samples ${ }^{21}$.

\section{TYPE 3}

Type 3 is represented with one sample and the style critique comparisons indicate that this type is a production of Chios.

9) Dupont 1998: 168; Carlson 2004: 26.

10) M. Lawall 1995, identified three sub-categories, as he named $S / 1, S / 2$ and $S / 3$ for the Samian amphoras, based on the foundlings in Athens. The Ceramus sample is similar to the Lewall's S/2 type. See Lewall 1995: 370, Fig. 70, Fig. 71.

11) Zeest named the late samples, that the form dated to $2^{\text {nd }}$ and $3^{\text {rd }}$ centuries B.C., as Ust'-Laba type.

12) Zeest 1960: 150. V. Grace diverges from Zeest in his study about the Samian Amphoras in 1971, and mentions that aforementioned amphoras are more than only one type. See Grace 1971: 79.

13) Lewall 1995: 219

14) Norskov 2004: 287

15) For Athens, see Lewall 1995: 220.

16) For Paros, see Empereur and Picon 1986: 504; for Rhodos and Peraia, see Şenol 2015: 193; Şenot et al. 2004: 357; for Samos, see Grace 1971: 67.

17) For Klazomenai, see Doğer 1986: 469-471, fig. 18; 1991: 707-708, Pic. 13, type 6; for Knidos, see Empereur et al. 1999: 109; for Halicarnassus, see Norskov 2004: 289; for Erythrae, see Carlson and Lawall 2005/2006: 35.

18) V. Grace argues that the form was first manufactured in Athens and spread over other centers in $4^{\text {th }}$ century B.C. Unlike Grace, on the contrary, M. Lawall thinks that there were many manufacturers of the form even in the $5^{\text {th }}$ century B.C. See Lewall $1995: 223$.

19) V. Gassner asserted that some of the mushroom-mouthed amphoras within the Nikandros group might have been manufactured in Ephesos. See Gassner 1997: 105 sq. M. Lawall reached the conclusion that mushroom-mouthed amphoras were manufactured in Ephesos, too. Aforementioned standpoints were proved by petrographical analysis. See Lawall 2004, 177; 2007: 48; Bezeczky 2013: 61.

20) Bezeczky 2013: 62.

21) For Klazomenai, see Hasdağl1 2012: 163, Fig. 9, nº 62. For Samos, see Grace 1971: P1. 15.13; Doğer 1991: 99, R.101. For Panskoe I necropolis, see Monochof and Rogov 1990: Table 6, n 38-39; Kac et al. 2002: Pl.48 AD 80, AD 90. For Halicarnassus, see Norskov 2004: 288, Fig. 4, Halicarnassus Type 3. 
The wine production in the Chios island started in $7^{\text {th }}$ century B.C. and continued until $1^{\text {st }}$ century B.C. ${ }^{22}$. Well-known by many ancient writers for the quality of its wines ${ }^{23}$, the island exported its products to a wide area, from the Mediterranean and Aegean basin to the Black Sea. Known to be expensive, it is narrated that these wines were sold for middle class buyers in lagyno $i^{24}$. The commercial amphoras used in the transportation of aforementioned wines ${ }^{25}$, have been showing a formal characteristic of outwardly sloping rimmed, short-thick necked, ovoidal body and elevated-pedestal in bracelet form since $7^{\text {th }}$ century B.C. These characteristics started to change since the last quarter of $6^{\text {th }}$ century B.C. and a bump was seen in the neck for a century. Beginning from the last quarter of $5^{\text {th }}$ century B.C. in the new form named as "new style", body structure was thinned and transformed to a triangular form. It was narrated that neck and handles got longer depending on the thinning. This elongation in the neck had almost become equal with the body length in the beginning of the $4^{\text {th }}$ century B.C. Along with these characteristics it seemed that the thinning continued and plastic obstacles in pedestal were removed in $2^{\text {nd }}$ century B.C. ${ }^{26}$.

The sample evaluated within the scope of the study is identified in form as outward-sloping rounded lip-edged, thin and long-necked, having oval sectional handles connecting to the shoulder from the upper part of the neck, a sharp shoulder-body pass and a triangular body. Pedestal-body pass is grooved (Pl. 2: 3). With the typological comparisons made by taking into consideration of present typological characteristics, the artifact can be dated to the third quarter of $4^{\text {th }}$ century B.C. ${ }^{27}$.

\section{TYPE 4}

Type 4, which was found among the amphoras in Ceramus, is classified in the Dressel 1 amphora type ${ }^{28}$.

Dressel 1 amphoras, which were considered as the successive of the Greco-Italic amphoras ${ }^{29}$, carried the quality wines produced in the Campania, Latium and Etruria regions in the Tyrrhen coasts of Italy ${ }^{30}$. They are the most common wine amphoras, which were seen in the Western Mediterranean in $1^{\text {st }}$ century B.C. ${ }^{31}$. The distribution of this form in the Eastern Mediterranean is limited. It is also narrated that they also carried different products like seashells and resin, except wine ${ }^{32}$. N. Lamboglia identified three sub-categories based on the differences in the mouth structure of this form ${ }^{33}$.

The Ceramus sample has a formal characteristics of upright mouth side, thin and long neck, oval-sectioned, vertical handles connecting to shoulder, sharp shoulder-body pass, stuffed, flat base, long bottom. The whole form, except one of its handles, is reserved (P1. 3: 4). Different than Dressel 1-A sub-type, the mouth structure of the present form has an upright appearance rather than the triangle. Besides, the pedestal was kept longer and the base was flattened. It is understood that the sample found in Keramos is Dressel 1-B type when these formal characteristics

22) Şenol 2003: 51; Whitbread 1995: 135; Doğer 1988: 88; Mattingly 1981: 78. Chios took side with Mithridates VI in $1^{\text {st }}$ century B.C. against Rome and the wine production of Chios was restricted by Rome along with many punishments later on. See Lagos 1998 : 36 .

23) It is narrated that three types of wine were used to be produced in the island and the sweet one was famous. See Athenaeus $I$, 32. Strabo narrates that the best wines in the Hellenic world were produced in Ariusia situated on the mountainous northwestern part of the island. See Strabo. 14.1.35. As a reflection of its popularity, The Old Plinius states that Julius Ceasar used to prefer Chios wine in his victory feasts. See HN.14.16.97.

24) Şenol 2003: 53.

25) It is thought that aforementioned amphoras even carry other products else than wine. As a result of DNA analysis on a Chian amphora found in the Oinousses shipwreck, residues of olive oil and tyme were encountered in the amphora by M.C. Hansson and F. Foley. See Hannson and Foley 2008: 1169; Demesticha 2011: 48.

26) For the typological improvement, see Şenol 2003: 52, Whitbread 1995: 135.

27) In 2006, approximately 500 commercial amphoras were identified in the Mazotos shipwreck found in the southern coasts of Cyprus. Chian amphoras consist of the majority of the amphoras dated to the third quarter of $4^{\text {th }}$ century B.C. The sample named as NM1 found in the cargo of the ship is quite similar to the Ceramus sample in form. See Demesticha 2011: 45, Fig. 5a, NM1. Another comparison sample used in date comes from the Chios-Oinousses shipwreck found in the northeastern coast of the Chios island in 2005. 350 commercial amphoras were found in the shipwreck dated to middle and third quarter of $4^{\text {th }}$ century B.C. For a similar sample, see Foley et al. 2009: 288, Fig. 12. For a similar sample dated to $4^{\text {th }}$ century B.C. in Athens, see Grace 1979 : Fig. 46.

28) H. Dressel was the first one identifying the form. See Dressel 1899. The form is also mentioned as Peacock and Williams 4. See Peacock and Williams 1986: 89

29) Zevi 1966: 212, Peacock 1971: 162 sq.; Bezeczky 2013: 100.

30) For the production centers, see Peacock 1971: 164; Peacock and Williams 1986: 69, 90.

31) Şenol 2000: 116.

32) Beltrán Lloris 1970; Benoit 1962; Tchernia 1986.

33) Lamboglia 1955: $246 s q$. 
are taken into consideration. As a result of the comparisons made with similar samples, the artifact should be dated to $1^{\text {st }}$ century B.C. ${ }^{34}$.

\section{TYPE 5}

Type 5, which is among the amphoras evaluated within the scope of this study and represented with two samples, enters into the Dressel 2-4 amphoras classification $^{35}$.

The form, which was produced in Kos in the Hellenistic period and was qualified as the successor of the type named as Koan Amphoras, was produced in many different centers, particularly in Campania region in Italy and Tarraconensis region in the northern part of the Spain ${ }^{36}$.

The DR 2-4 amphoras, which were seen lighter and more useful in terms of weight/capacity rate, as a result of its wall structure thinner than its predecessor DR1-B ${ }^{37}$, got into use until to the beginning of the $3^{\text {rd }}$ century A.D. starting from the middle of $1^{\text {st }}$ century B.C. ${ }^{38}$. The form has a very wide distribution area. Available data show that it was exported to a wide geography particularly in the Western Mediterranean settlements to the Britannia in north, from Egypt in the Eastern Mediterranean to India through the Red $\mathrm{Sea}^{39}$. As these types of amphoras were used in wine transportation ${ }^{40}$, it is also known that they carried products like olive oil, garum and dates ${ }^{41}$.

Two samples which were evaluated within this group were found in Ceramus. The first sample has slightly outward and rounded mouth structure. The neck is long, cylindrical and narrow. Sharp grooves are observed in the neck-shoulder and shoulderbody passes. The handles are similar to right-angled spur. The body has a cylindrical form (Pl. 3: 5). The second sample has a similar mouth structure and right-angled handles, but the mouth diameter is wider and the neck is shorter (P1. 3: 6). In the light of these typological data, as a result of the comparisons made with similar samples, the present samples can be dated to the first quarter and the end of $1^{\text {st }}$ century A.D. ${ }^{42}$

\section{TYPE 6}

Type 6, which is discussed within the scope of this study, is represented by a sample and enters into the category of amphoras identified as LRA-4 $4^{43}$.

It is thought that this form, which was thought to be produced in the Palestinian costs, in and around $\mathrm{Gaza}^{44}$, carried wine and sesame ${ }^{45}$. The aforementioned form was exported to a wide geography particularly to the Western Mediterranean, Italy in the west and to the south of France ${ }^{46}$. Four sub-categories are identified by observing the formal characteristics like out-stretching or flatness of mouth, length or shortness of neck, narrow-cylindrical or wide body ${ }^{47}$. It was determined that the early samples were short, wide-mouthed and bodied; the form was evolved to a more cylindrical structure as the mouth and the body narrowed in the improvement of the form.

The form found in Ceramus has a structure of rounded mouth base and lightly out-stretched mouth side. The handles are vertical and oval sectioned connecting to the upper body from shoulder and the body can be identified as cylindrical (Pl. 3: 7). In the light of this typological data, the present sample should be evaluated within the sub-category of LR4$\mathrm{B} 1$, when the classification of D. Pieri is taken into consideration. This sub-category must have been

34) Bezeczky 2004: 89, $\mathrm{n}^{\circ} 4$.

35) The other names identified for this form are; Augst 5, Peacock and Williams 10, Koan, Ostia 51, Camulodunum 182-183, Callender 2, Benghazi ER4, Brukner Type-6, Lamboglia 5, Pompeii 3-8. See Şenol 2000: 128; 2003: 46; Ozanic 2005: 139; Bezeckzy 2005: 36; 2013: 129; Peacock and Williams 1986: 105. The form takes its name from the classification made by H. Dressel. See Dressel 1899, Senol 2009: 136; Moore 1995: 1 sq.

36) Sealey 1985: 128; Bezeczky 2013: 130. For the corn production, see Empereur 1986: 599 sq.

37) Williams and Peacock 1986: 6, Fig. 1; Williams 2004: 444.

38) Bezeczky 2005: 38; 2013: 129.

39) Williams 2004: 441; Gupta et al. 2001: 7; Bezeczky 2013: 129; Senol 2003: 49.

40) Arthur and Williams 1992: 250. Bezeczky 2013: 131.

41) Senol 2004: 49.

42) For similar samples, see Ephesos Bezeczky 2004: 91, Kt.Nr.13; for Marmaris, see Şenol 2003: 48.

43) Aforementioned form is also mentioned in literature as Gaza, Almagro 54, Kartaca LR4, Riley LR4, Kuzmanov 14, Augst 60, Keay 54, Peacock-Williams 49, Egloff 182. See Șenol 2000: 244, Keay 1984: 278; Riley 1979: 223 sq.; Peacock and Williams $1986: 198$.

44) For the petrographical analysis made on the samples found in Caesarea hippodrome and production center suggestion, see Riley 1975: 30; 1979: 220; Peacock 1984: 24; Bezeczky 2013: 171. For the production wastes found in the northern part of Negev, see Regev 2004: 348.

45) Senol 2000: 246.

46) Şenol 2009: $158 s q$.

47) Majcherek 1995: 172; Şenol 2000: 244 
used in the third quarter of the $5^{\text {th }}$ century and the middle of the $6^{\text {th }}$ century A.D. ${ }^{48}$.

\section{TYPE 7}

Type 7, which was found in Ceramus and taken part in the amphoras of the Late Roman period, takes place in LRA-1 amphoras group ${ }^{49}$.

The amphoras partaking in this group were produced in Cyprus, the Syrian coasts, Rhodes and Peraea and particularly in the Cilicia coasts; and were widely used in the Aegean and Mediterranean geographies ${ }^{50}$. As a result of the studies, it was understood that LRA-1 was used in wine and oil olive transportation $^{51}$. Three sub-categories of the form were determined by M. Bonifay and D. Pieri, by observing the differences like neck thickness and height of the form ${ }^{52}$.

The sample found in Ceramus has a flat structure of rounded mouth base. It has a cylindrical neck, which is short and opening convex to the mouth. The oval sectional handles connect with the body starting from the side of the mouth. The body is narrowing to the pedestal under the shoulder, and grooves are there (Pl. 4: 8). In terms of typology, the present sample should be evaluated within the LRA1-b sub-category, when the structure of rightangled handles, the thickness of neck and the total height of $40 \mathrm{~cm}$ are taken into consideration. The artifact can be dated to the second half of $6^{\text {th }}$ century A.D and the first quarter of $7^{\text {th }}$ century A.D. within the scope of the analogical researches ${ }^{53}$.

\section{TYPE 8}

Type 8 , which was taken into evaluation within the scope of this study, is represented by a sole sample. Aforementioned amphora is named as LRA-2 amphora in literature ${ }^{54}$.

LRA-2 amphoras, which were thought to be the successor of Dressel Type 24 in terms of typology ${ }^{55}$, were used for a long period from the middle of the $4^{\text {th }}$ century to $9^{\text {th }}$ century ${ }^{56}$. LRA-2 amphoras are identified as Aegean origin, with reference to production centers ${ }^{57}$. Aforementioned centers are indicated as Northeastern Peloponnessos, Chios, and Oltina in Romania ${ }^{58}$. These amphoras, which were thought to be used in mastic, myrtle resin, turpentine and olive oil in sweet wine transportation, particularly in wine and olive oil transportation, are mostly found in the Eastern Mediterranean and North Africa $^{59}$. Three sub-types A, B and C are identified for the form ${ }^{60}$.

The sample found in Ceramus has a sharp profile in the outer surface, triangle form, and a high mouth with a rounded lip. The handles with thick and rounded-sectioned structure starting from the neck, combine with the shoulder. The body of the form, which has a high, conical neck, has an ovoid structure; and is narrowed in a concave angle between the body-pedestal (Pl. 4: 9). When the long-necked structure, rising handles based on lengthening of the neck and ovoid structure of the body else than spherical, with reference to this definition, the present

48) Pieri 2005: $105 s q$.

49) Aforementioned naming was made by J. Riley in 1979 and widely accepted in literature. See Riley 1979: 212 sq. These amphoras also take part in the literature as Agora M333, Ballana Type 6, Benghazi LR1, Kartaca LR1, Keay 18, Keay 53, Peacock-Williams 44, Scorpan 8B, Kuzmanov 13, British Bii. See Peacock and Williams 1986: 185-187.

50) Şenol 2004: 12; Lang 1976: 81; Demesticha 2003: 471; Empereur and Picon 1989: 239, fig. 18; Alkaç 2012: 325; Ferrazzoli 2010: 46; Aslan 2015: 336 sq.; Alkaç 2012: 325; 2013: 114; Jacobsen 2004: 145; Ferrazzoli-Ricci 2007: 690; Michaelides 1996: 149; Empereur and Picon 1989: 237 sq.; Tekocak and Zoroğlu 2013: 44; Şenol 2008: 115 sq.

51) Senol 2000: 200; 2000: 37 sq.; 1998: 93; Peacock and Williams 1989: 186.

52) Bonifay and Pieri 1995: 108; Şenol 2009: 244 sq.

53) For similar samples in terms of typology, see Ephesus. Bezeczky 2013: 159; for Kekova, see Aslan 2015: 365, Fig. 2.18; for Side, see Dündar 2012: 46, Fig. 5; for Silifke, see Alkaç 2013: 114, Fig. 9; for Korykos, see Alkaç 2012: 323; for Taşucu, see Şenol 2004: 13, Pic. 8; for Alexandria, see Şenol 2000: Lev. 31, Fig. 109; for South Gaul, see Pieri 1998: 89 sq.; for Kelenderis, see Tekocak and Zoroğlu 2013: 121; for Burgaz, see Leidwanger et al. 2015: 304, Fig. 5; for İçel, see Şenol and Kerem 2000: 95, Kt. Nr.18; for Yassiada, see Bass and Doorninck 1982: 157, Fig. 8.3; for Miletos, see Lüdorf 2006: Taf. 16, A108.

54) It is also known as LRA-2 Amphoras, Carthage LRA-2, Benghazi LRA-2, Peacock-Williams 43, Beltran 71, Scorpan 7A, British

B1, Keay 65, Kuzmanov 19, Sabratha Type 25. See Şenol 2000: 179; Bezeczky 2013: 160; Peacock and Williams 1986: $182-184$.

55) Opait 2004: 295; 2007: 627 sq.

56) For the chronological findings, see Şenol 2009: 149.

57) Pieri 2005: 99.

58) For Argos and its around, see Pieri 2005: 99; for Sikyon, see Tzavella et al. 2014: 93. For the other producton centers, see Şenol 2003: 97; Riley 1979: 219; Bonifay and Villedieu 1989: 25 sq.; Karagiorgou 2000: 129 sq.; Bezeczky $2013: 161$.

59) Şenol 2015: 248; 2009: 149; Aslan 2015: 338; Şenol 2000: 182.

60) Şenol 2000: 187; 2003: 97. 
sample can be evaluated within the LRA-2-b subtype in terms of typology. When the aforementioned sub-type is evaluated in terms of analogical perspective, it should be dated to between the second quarter of the $6^{\text {th }}$ century and $7^{\text {th }}$ century A.D. ${ }^{61}$.

\section{TYPE 9}

The type 9 takes part in commercial amphoras of Aegean origin in the Late Roman Period and enters into the LRA-13 amphora group ${ }^{62}$. The data obtained from the excavations of Benghazi, Yassiada shipwreck, and Saraçhane, indicates that type 9 was used as the late version of the LRA-2 in terms of chronology ${ }^{63}$. As a result of excavations made in the Halasarna settlement in Kos island, the production of LRA-13 amphoras was proved in the island ${ }^{64}$. These amphoras, which were used in oil olive/wine - or both - transportation, spread over Marmara, Cyprus and Northern Africa, and particularly in Aegean coasts.

The sample discovered in Ceramus has an outstretched rounded mouth, cylindrical and short neck, and oval-sectioned vertical handles connecting on the shoulder from the middle of the neck, in terms of typology. The body should be in spherical appearance ( $\mathrm{Pl}$. 4: 10). The aforementioned form should be dated to the first half of the $7^{\text {th }}$ century A.D. with analogical evaluations, with reference to its characteristics ${ }^{65}$.

\section{TYPE 10}

Type 10 partaking among Late Roman amphoras discovered in Ceramus, is among amphoras of Samos-Cistern ${ }^{66}$.
The amphoras partaking this group were discovered in Samos in large numbers and variety ${ }^{67}$. The data received from ceramic dumps supports that Samos was a production center ${ }^{68}$. Samos-cistern type was thought to be produced in many different centers like Meander Valley in the Western Anatolia, Halicarnassus, and Elaea, along with Samos ${ }^{69}$. The amphoras, which were spread to the Eastern Mediterranean, the east of Alps, Ampurias in the Western Mediterranean and the Black Sea, particularly in Aegean coasts, are thought to be used mostly in olive oil and wine transportation ${ }^{70}$.

The sample discovered in Ceramus has a rounded tip and out-stretched mouth. The neck shows a structure widening to the shoulder. The handles are twinsectioned, and start from the neck and connect to the shoulder-body pass. The body in the cylindrical structure widens slightly to the bottom part like a bag. The form, whose bottom part is not preserved, should have a conical pedestal (Pl. 5: 11). The Aforementioned sample can be dated to the interval of $6^{\text {th }}-7^{\text {th }}$ centuries, pursuant to the typological evaluations $^{71}$.

\section{TYPE 11}

Type 11 is outward slanting-mouthed, narrow and long-necked, and has oval-sectioned and vertical thin handles. Shoulder-body pass of the form is kept sharp and is triangle-bodied. The bottom part of the pedestal was found broken (Pl. 5: 12).

In terms of typology, making the neck and the handles as long as almost the body, being the neckbody passes sharp and being the body triangle suggest that this amphora was manufactured in the

61) Similar samples, for Gaul, see Pieri 1998: 100; for Ephesus, see Bezeczky 2013: 160; for Sycthia, see Opait 2004: 296, Fig. 10; for Knidos, see Aslan 2015: 113, Fig. 22; for Yassiada, see Doorninck 1982: Fig. 1; 1989: 249, Fig. 1.

62) J. Riley identified this group that he discovered in Bingazi as LRA-13, and this definition was widely accepted in literature. The other names of the form are in the literature as; Kuzmanov Type 20, Scorpan Type 7-A3, Peacock and Williams Class 54, Hayes Type 29. See Kuzmanov 1973; Scorpan 1977; Riley 1979; Peacock and Williams 1986; Hayes 1992.

63) Şenol 2015: 248.

64) Diamanti 2010: 1 sq.; Didimou 2014: 170. It is thought that LRA-13 production was made in the workshops in Cyprus. See Demesticha 2005: 169

65) Similar samples, for Kos, see Diamanti 2010: Fig. 1.b; for Yassıada, see Bass and van Doorninck 1982: 157, CA13; for Bingazi, Riley 1977: Fig.93, Kt.Nr.373; for Saraçhane, see Hayes 1992: Type 29, Fig. 23.3.

66) Form is also named as Agora M273, Keay LXVII and LRA-8. See Keay 1984: 358, Fig. 66; Pieri 2005: 132.

67) A large number of samples were discovered in a cistern excavations in Samos made by Hans-Peter Isler. See Isler 1969: 202. See also Arthur 1990: 282.

68) Şenol 2009: 157; Bezeckzy 2013: 157; Arthur 1985: 252; 1990: 288; $1998: 167$.

69) Bezeczky indicates that the meander valley was one of the probable production centers. See Bezeczky 2013: 157. For Halicarnassus see, Williams 1990: 296. J.-Y. Empereur and M. Picon found a workshop in Elaea, that the precesors of the form were produced. See Emperreur and Picon 1986: 143; Bezeczky 2013: 157; Arthur 2005: Samos Cistern Type.

70) Bezeczky 2013: 157; Şenol and Kerem 2000: 100; Şenol 2000: 193; Sagui 1998: 167; Şenol 2009: 157; Pieri 2005 : 136.

71) Similar samples, for Bodrum, see Baas and Doorninck 1971: Pl. 2, Fig. 8; for İçel, see Şenol and Kerem 2000: 99, Kt.Nr.25; for Napoli, see Arthur 1989: Fig. 4; for Side, see Dündar 2012: 54, Fig. 19; for Nicopolis, see Reynolds and Pavlidis 2014: 462, Fig. 9 , 1. 
Chios island in the Hellenistic period. Since the bottom part of the pedestal was broken, no any certain conclusion could be reached about its production center.

\section{TYPE 12}

In terms of formal characteristics, another amphora, whose production center could not be identified, is defined as outward slanting mouthed, rounded flaring-rimmed, ovoidal bodied, having high-necked, oval-sectioned vertical handles, carved interior with high pedestal (Pl. 5: 13).

It is narrated that it was quite popular to use pedestals with carved interior in the Aegean and Mediterranean geographies, in the early Hellenistic period. The Cyprus productions have been high cylindrical-necked and have high pedestal with the carved interior in a similar way to Chios productions since $4^{\text {th }}$ century B.C. ${ }^{72}$. When the formal characteristics are taken into consideration, the form, which is probably the productions of Cyprus, can be dated to the early Hellenistic period.

\section{GENERAL EVALUATION}

Ceramus, which was located on the northern coasts of the Ceramus gulf, has been an important coastal settlement. It is proved that the city had a privileged position in the Caria region with the high tax to Delian League in $5^{\text {th }}$ century B.C. ${ }^{73}$.

During the 2012 survey, the commercial amphoras discovered in the city were classified in terms of typology, and totally 12 different types were identified. Although the category or production centers of 10 types out of aforementioned 12 types are certainly identified, the production centers of the remaining 2 samples could not exactly be identified.

In the earliest amphora sample (Type 1, Samian amphora that was dated to third quarter of $5^{\text {th }}$ century B.C.), which was taken to evaluation, it is possible to see the commercial relations the city established with the South Ionia. It is also proved with the amphora sample of the Mushroom Type amphora that these relations had been maintained during $4^{\text {th }}$ century B.C.

The Roman rule starting in 129 B.C. had reflections on the commercial relations of the region, and the West Mediterranean and Italian production wines were transported to Ceramus with Dressel Type-1 and later on with Dressel Type-2-4. By this way, the city, which was a frequent destination on the Aegean commercial route since the Archaic period, seems having been included in the Western route.

The LRA-4 and LRA-1 amphoras discovered within the scope of the research, are important data reflecting the Ceramus' commercial relations with Cilicia and the Levant coasts in the Eastern Mediterranean between $5^{\text {th }}$ and $7^{\text {th }}$ centuries A.D. Likewise, the existence of LRA-2 and LRA-13 and the SamosCistern Type amphoras, which were produced on the Eastern Aegean coasts, has been reflecting the continuance of the Ionian commerce existing since the Archaic period.

As a conclusion, it can be said that Ceramus established uninterrupted commercial relations with the Cyprus, Cilicia and the Levant shores and Italy in west, and particularly in the Aegean settlements, from the Archaic period to the Early Byzantine period, with reference to present commercial amphora data.

A.K. and A.Y.

\section{CATALOGUE}

1

Type: Samian Amphora

Clay: 2.5 YR 5/6 Red

Surface: 2.5 YR 5/6 Red

Measurements: Rim Diam. 9.5 cm, H. 61 cm, Pedestal Diam. $3.5 \mathrm{~cm}$

Dating: $2^{\text {nd }}$ half of the $5^{\text {th }}$ Century B.C.

Parallel Examples: Lawall 1995: 370, Fig. 70,

Fig. 71.

Pl. 2: 1
2

Type: Mushroom Type Amphora

Clay: 7.5 YR 6/4 Light Brown

Surface: 7.5 YR 6/4 Light Brown

Measurements: Rim Diam. 14 cm, H. 74 cm

Dating: $2^{\text {nd }}$ half of the $4^{\text {th }}$ Century B.C.- $4^{\text {th }}$ quarter of the $4^{\text {th }}$ Century B.C.

Parallel Examples: Hasdağlı 2012: 163, Fig. 9, nº 62; Grace 1971: Pl. 15.13; Doğer 1991: 99, R.101; Monachov and Rogov 1990: Table 6, n' 38-39; Kac et al. 2002: Pl. 48 AD 80, AD 90; Norskov 2004: 288, Fig. 4, Halicarnassus Type 3. 
3

Type: Chian Amphora

Clay: 5 YR 7/6 Reddish Yellow

Surface: 5 YR 7/6 Reddish Yellow

Measurements: Rim Diam. 10 cm, H. 98 cm Pedestal Diam. $3 \mathrm{~cm}$

Dating: $3^{\text {rd }}$ quarter of the $4^{\text {th }}$ Century B.C.

Parallel Examples: Demesticha 2011: 45, Fig. 5a, NM1; Foley et al. 2009: 288, Fig. 12; Grace 1979: Fig. 46.

\section{4}

Type: Dressel Type-1b

Clay: 2.5 YR 5/6 Red

Surface: 2.5 YR 5/6 Red

Measurements: Rim Diam. 15 cm, H. 104 cm

Dating: $1^{\text {st }}$ Century B.C.

Parallel Examples: Bezeczky 2004: 89, nº 4.

\section{5}

Type: Dressel Type-2-4

Clay: 5 YR 6/6 Reddish Yellow

Surface: 5 YR 6/6 Reddish Yellow

Measurements: Rim Diam. 10.4 cm, H. $81 \mathrm{~cm}$

Dating: $1^{\text {st }}$ Century A.D.

Parallel Examples: Bezeczky 2004: 91, Kt.Nr.13; Şenol 2003: 48.

\section{6}

Type: Dressel Type-2-4

Clay: 2.5 YR 5/4 Reddish Brown

Surface: 2.5 YR 5/4 Reddish Brown

Measurements: Rim Diam. 12 cm, H. $20.5 \mathrm{~cm}$

Dating: $1^{\text {st }}$ Century B.C.

Parallel Examples: Bezeczky 2004: 91, Kt.Nr.13; Şenol 2003: 48.

\section{7}

Type: LRA-4b

Clay: 2.5 YR 5/6 Red

Surface: 2.5 YR 5/6 Red

Measurements: Rim Diam. 9.6 cm, H. 69.8 cm, Pedestal Diam. $2.5 \mathrm{~cm}$

Dating: $3^{\text {rd }}$ quarter of the $5^{\text {th }}$ Century- $2^{\text {nd }}$ half of the $6^{\text {th }}$ Century

Parallel Examples: Pieri 2005: 105 sq.

\section{8}

Type: LRA-1b

Clay: 10 R 7/6 Yellow

Surface: 10 R 7/6 Yellow

Measurements: Rim Diam. 8.2 cm, H. $40.6 \mathrm{~cm}$, Pedestal Diam. $2 \mathrm{~cm}$

Dating: $3^{\text {rd }}$ quarter of the $6^{\text {th }}$ Century A.D. $-1^{\text {st }}$ quarter of the $6^{\text {th }}$ Century A.D.

Parallel Examples: Bezeczky 2013: 159; Aslan 2015: 365, Fig. 2.18; Dündar 2012: 46, Fig. 5; Alkaç 2013: 114, Fig. 9; 2012: 323; Şenol 2004: 13, Res.8; 2000: Lev. 31, Şek. 109; Pieri 1998: 89 sq.; Tekocak and Zoroğlu
2013: 121; Leidwanger et al. 2015: 304, Fig. 5; Şenol and Kerem 2000: 95, Kt. Nr.18; Bass and Doorninck 1982: 157, Fig. 8.3; Lüdorf 2006: Taf. 16, A108.

9

Pl. 4: 9

Type: LRA-2b

Clay: 2.5 YR 5/6 Red

Surface: 2.5 YR 5/6 Red

Measurements: Rim Diam. 6.4 cm, H. $60.2 \mathrm{~cm}$, Pedestal Diam. $2 \mathrm{~cm}$

Dating: $2^{\text {nd }}$ half of the $6^{\text {th }}$ Century A.D.-1st half of the $7^{\text {th }}$ Century A.D.

Parallel Examples: Pieri 1998: 100; Bezeczky 2013: 160; Opait 2004: 296, Fig. 10; Aslan 2015: 113, Fig. 22; Doorninck 1982: Fig. 1; 1989: 249, Fig. 1.

\section{0}

PI. 4: 10

Type: LRA-13

Clay: 5 YR 5/3 Reddish Brown

Surface: 5 YR 5/3 Reddish Brown

Measurements: Rim Diam. $8 \mathrm{~cm}$, H. $17 \mathrm{~cm}$

Dating: $1^{\text {st }}$ half of the $7^{\text {th }}$ Century A.D.

Parallel Examples: Diamanti 2010: Fig. 1.b; Bass and Van Doorninck 1982: 157, CA13; Riley 1977: Fig. 93, Kt.Nr.373; Hayes 1992: Tip 29, Fig. 23.3.

11

Pl. 5: 11

Type: Samos-Cistern

Clay: 10 R 5/8 Red

Surface: 10 R 5/8 Red

Measurements: Rim Diam. $10.8 \mathrm{~cm}, H .47 \mathrm{~cm}$

Dating: $1^{\text {st }}$ half of the $6^{\text {th }}$ Century A.D. $-1^{\text {st }}$ half of the $7^{\text {th }}$ Century A.D.

Parallel Examples: Baas and Doorninck 1971: P1. 2, Fig. 8; Şenol and Kerem 2000: 99, Kt.Nr.25; Arthur 1989: Fig. 4; Dündar 2012: 54, Fig. 19; Reynolds and Pavlidis 2014: 462, Fig. 9, 1.

12

PI. 5: 12

Type: Chian (?)

Clay: 5 YR 7/8 Reddish Yellow

Surface: 5 YR 7/8 Reddish Yellow

Measurements: Rim Diam. $12 \mathrm{~cm}, H .73 .2 \mathrm{~cm}$, Pedestal Diam. $3 \mathrm{~cm}$

Dating: Hellenistic period (?)

Parallel Examples: -

13

Pl. 5: 13

Type: Cyprus (?)

Clay: 7.5 YR 6/6 Reddish Yellow

Yüzey: 7.5 YR 6/6 Reddish Yellow

Measurements: Rim Diam. 10.2 cm, H. 68 cm,

Pedestal Diam. $3.6 \mathrm{~cm}$

Dating: Early Hellenistic period (?)

Parallel Examples: - 
PLATE 1

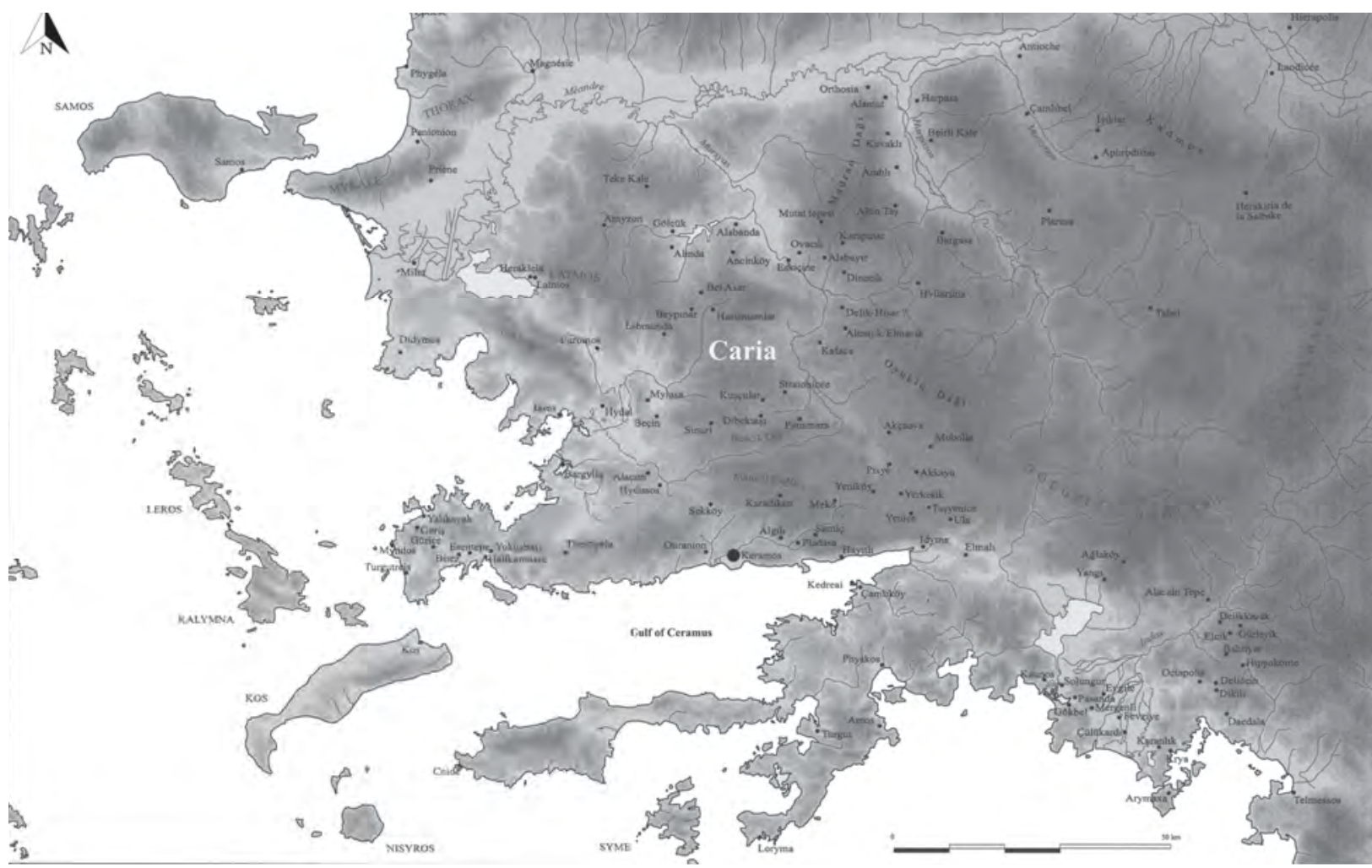

Fig. 1: Ancient Caria Region and the location of Ceramus (adapted from Henry 2008: 18, Fig. 1).

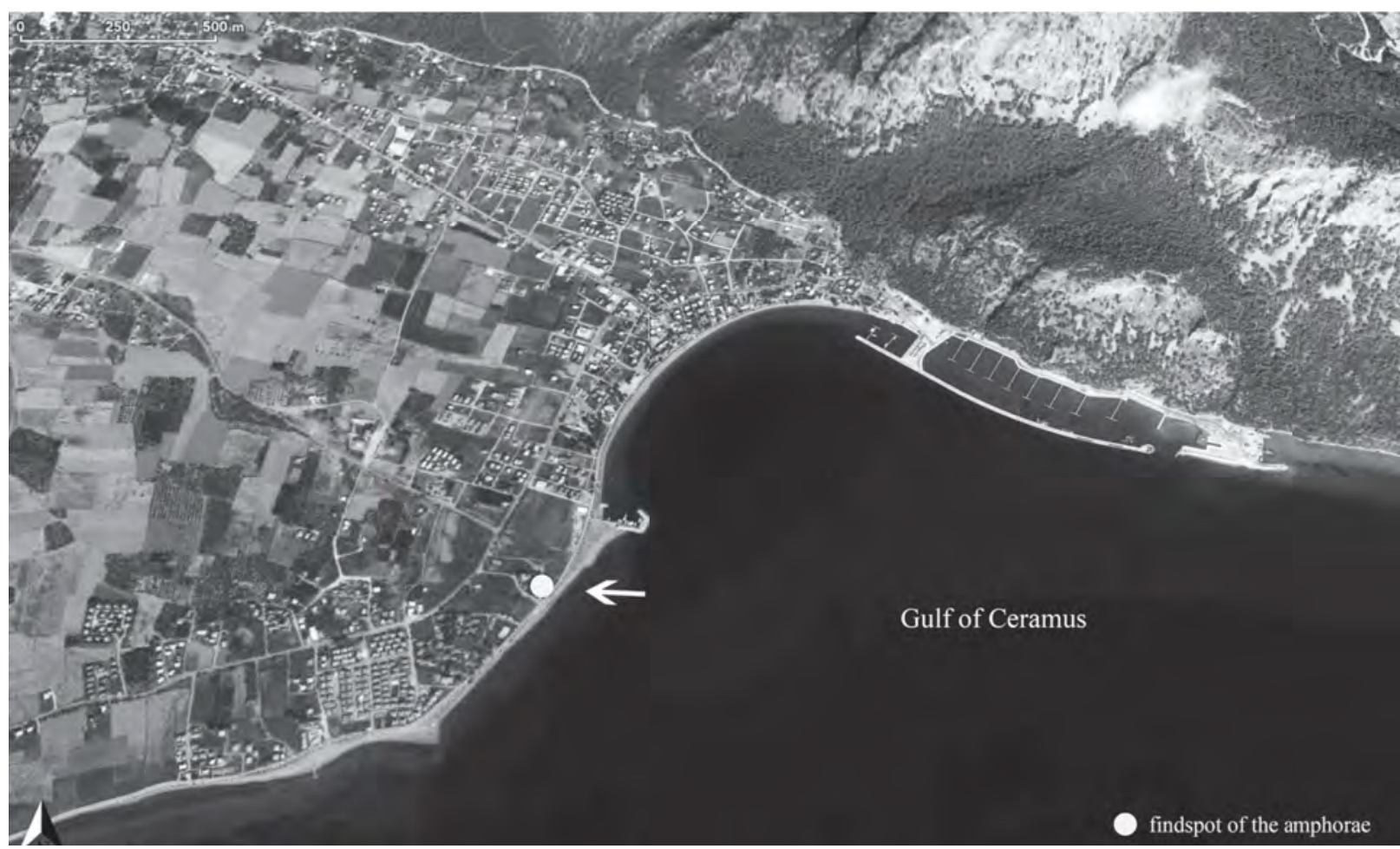

Fig. 2: Aerial view of modern Ören settlement and findspot of the amphoras (adapted from Apple Maps). 
ABUZER KIZIL and ASILL YAMAN

\section{PLATE 2}
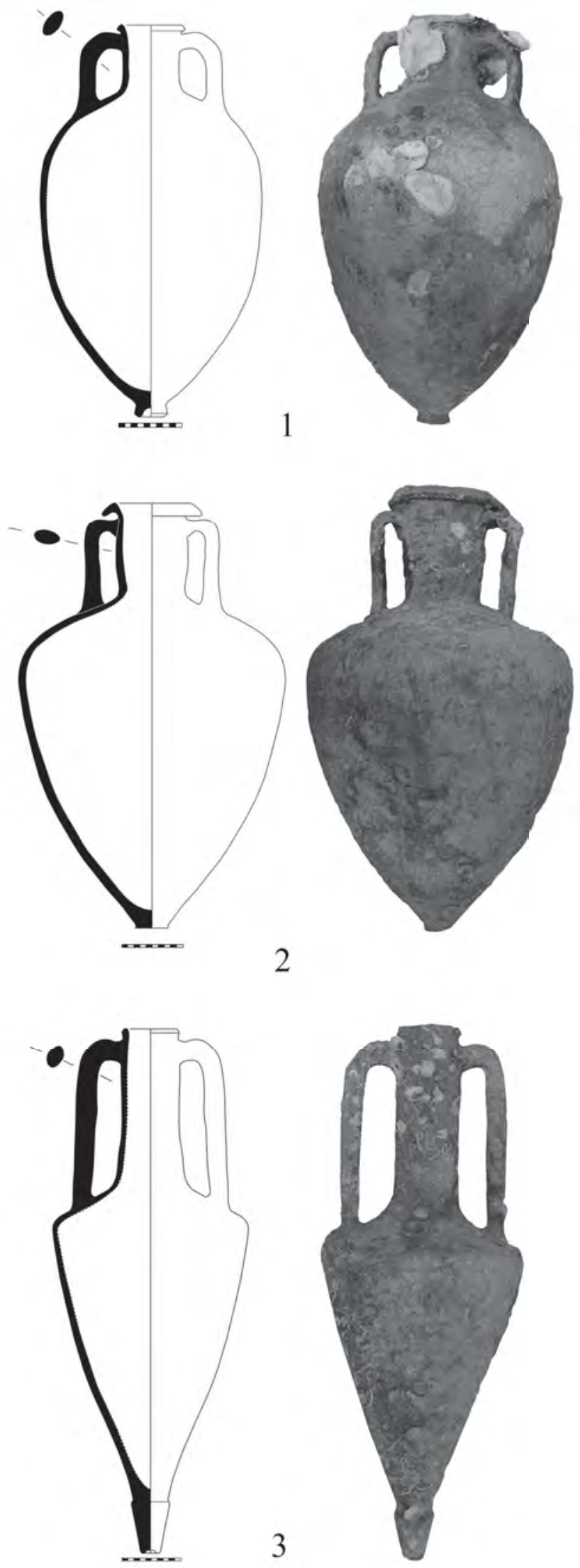

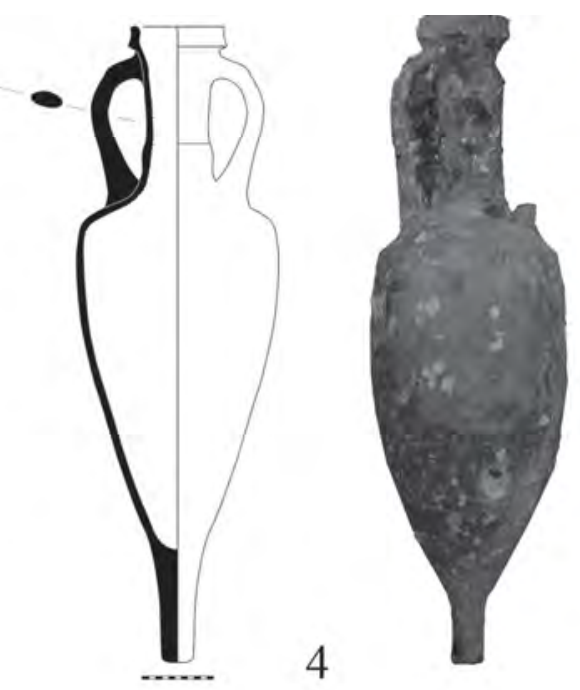

PLATE 3
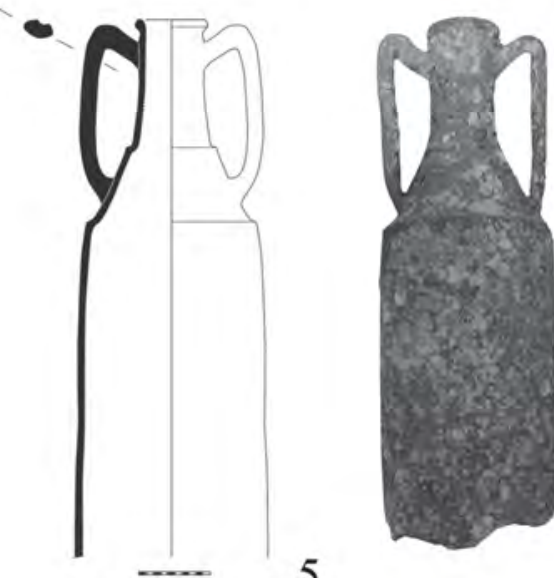

5

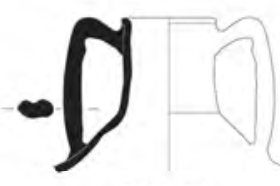

6
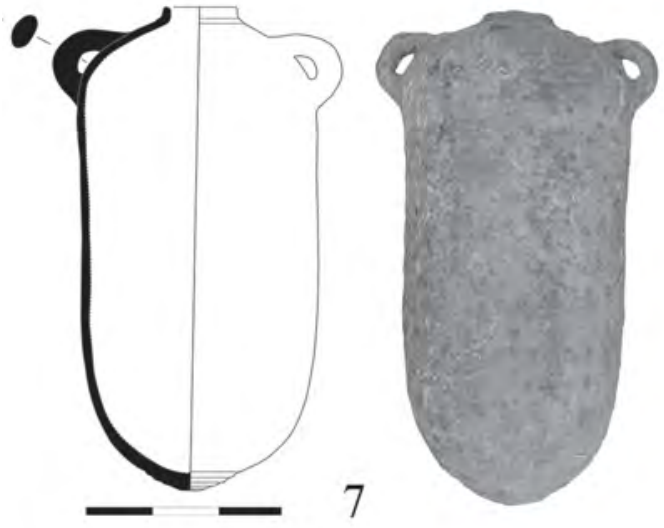
ABUZER KIZIL and ASIL YAMAN

PLATE 4
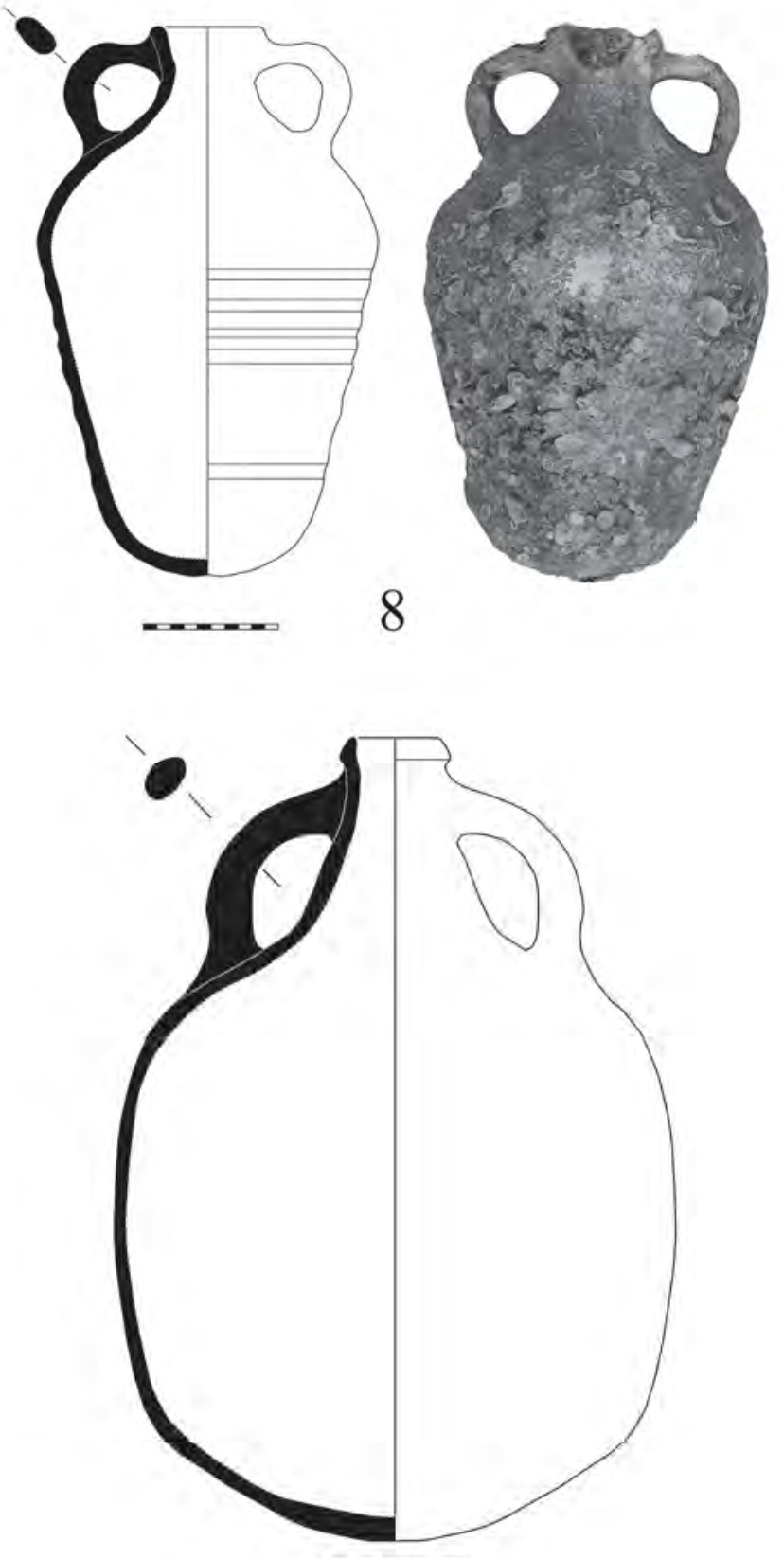

9

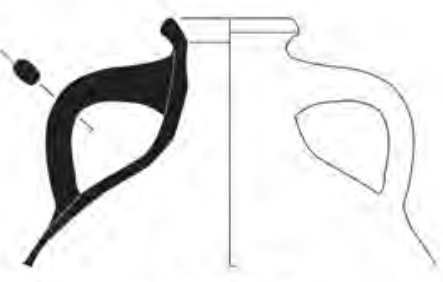

10 
PLATE 5
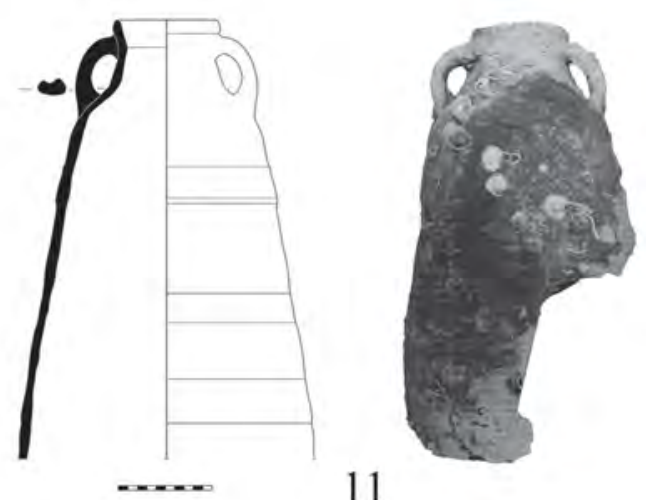

11
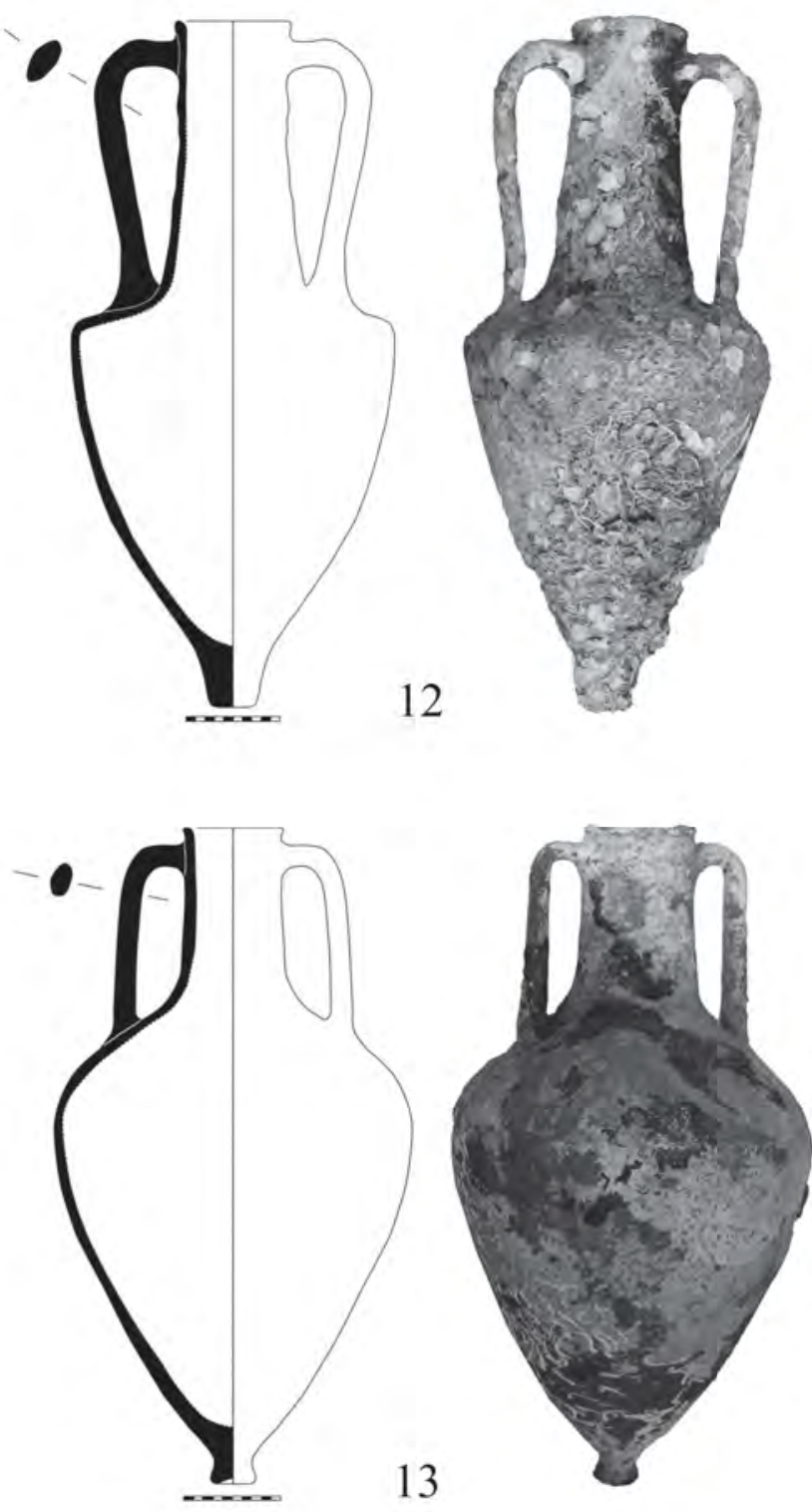


\section{BIBLIOGRAPHY}

Alkaç, E., 2012: "Korykos (Kilikia) Yüzey Araştırmalarında Bulunan LR1 Amphoraları", Olba 20: 323344.

- 2013: "Silifke Müzesi'nden Doğu Akdeniz Üretimi Amphoralar", Cedrus 1: 107-124.

Aslan, E., 2015: "Kekova Adas1 2012-2013 Y111 Sualtı Araştırmalarında Bulunan Amphoraların Tipolojik Değerlendirmesi”, Olba 23: 321-369.

Arthur, P., 1998: "Eastern Mediterranean amphorae between 500 and 700: a view from Italy", in Saguì, L. (ed.), Ceramica in Italia: VI-VII secolo. Atti del convegno in onore di John W. Hayes. Roma, 11-13 maggio 1995, Firenze: 157-184.

- 2005: "Samos Cistern Type", in Keay, S. and Williams, D.F. (eds.), Roman Amphorae. A digital resource, Southampton.

Arthur, P. and Williams, D.F., 1992: "Campanian wine, Roman Britain and the Third century A.D.", JRA 5: 250-260.

Bass, G.F. and Van Doorninck, F.H., 1982: Yassi Ada I. A Seventh Century Byzantine Shipwreck, Texas.

Benoit, F., 1962: "Relations commerciales entre le monde ibéro-punique et le Midi de la Gaule de l'époque archaïque à l'époque romaine", REA 63: 321-330.

Beltrán Lloris, M., 1970: Las ánforas romanas en España, Zaragoza.

Bezeczky, T., 2004: "Early Roman Food Import in Ephesus: Amphorae from the Tetragonos Agora", in Eiring, J. and Lund, J. (eds.), Transport Amphorae and Trade in the Eastern Mediterranean, Acts of the International Colloquium at the Danish Institute at Athens, September 26-29, 2002, Athens: 85-97.

- 2005: "Roman Amphorae from Vindobona", in Krinzinger, F. (ed.), Vindobona-Beiträg zu ausgewählten Keramikgattungen in ihrem topographiscen Kontext: 35 109.

- 2013: The Amphorae of Roman Ephesus, Wien.

Bonifay, M. and Piéri, D., 1995: “Amphores du Ve au $\mathrm{VII}^{\mathrm{e}}$ s. à Marseille: nouvelles données sur la typologie et le contenu", JRA 8: 94-120.

Bonifay, M. and Villedieu, F., 1989: "Importations d'amphores orientales en Gaule (Ve-VII siècle)", in Déroche, V. and Speiser, J.M. (eds.), Recherches sur la céramique byzantine, Actes du colloque EFA-Université de Strasbourg Athènes 8-10 avril 1987, BCH Suppl. 18: 17-46.

Cankardeş Şenol, G., Şenol, A.K. and Doğer, E., 2004: "Amphora Production in the Rhodian Peraea in the Hellenistic Period", in Eiring, J. and Lund, J. (eds.), Transport Amphorae and Trade in the Eastern Mediterranean, Acts of the International Colloquium at the Danish Institute at Athens, September 26-29, 2002, Athens: 353-360.

Carlson, N.D., 2004: Cargo in context: The morphology, stamping, and origins of the amphoras from a fifth-century B.C. Ionian shipwreck, Unpublished $\mathrm{PhD}$ Thesis (The University of Texas), Austin.
Carlson, N.D. and Lawall, M.L., 2005/2006: "Towards a Typology of Erythraian Amphoras", Skyllis 7: 33-40.

Demesticha, S., 2003: "Amphora Production on Cyprus during the Late Roman Period", in Bakirtzis, Ch. (ed.), Actes de VII Congrès international sur la céramique médievale en Méditerranée, Thessaloniki, 11-16 Octobre 1999, Athens: 469-476.

- 2005: "Some thoughts on the production and presence of the Late Roman Amphora 13 on Cyprus", Halicarnassian Studies 3: 169-178.

- 2011: "The $4^{\text {th }}$ Century-BC Mazotos Shipwreck, Cyprus: a Preliminary Report", IntJNautA 40.1: 39-59.

Diamanti, C., 2010: "Stamped Late Roman/ProtoByzantine amphoras from Halasarna of Cos, ReiCretActa 41: 1-8.

Didimou, S., 2014: "Local Pottery Production in the Island of Cos, Greece from the early Byzantine Period", $L R C W$ 4: 169-180.

Doğer E., 1986: "Premieres remarques sur les amphores de Clazomènes", in Empereur, J.-Y. and Garlan, Y. (eds.), Recherches sur les amphores grecques, BCH Suppl. 13: 461-471.

- 1988: Klazomenai Kazısındaki Arkaik Dönem Ticari Amphoralarl, Unpublished PhD Thesis (Ege University), İzmir.

- 1991: Antik Çağda Amphoralar, İzmir.

Dressel, H., 1899: Corpus Inscriptionum Latinarum. Berlin.

Dupont, P., 1998: "Archaic East Greek Trade Amphoras", in Cook, R.M. and Dupont, P., East Greek Pottery. New York.

Dündar, E., 2012: “A Group of Amphorae from Side Museum and a New Type of Amphora: The Lycian Amphora?", AA 2012/1: 43-61.

Empereur, J.-Y., 1986: "Un atelier de Dressel 2-4 en Égypte au III" siècle de notre ère", in Empereur, J.Y. and Garlan, Y. (eds.), Recherches sur les amphores grecques, BCH Suppl. 13: 599-608.

Empereur, J.-Y. and Picon, M., 1986: "Premieres remarques sur les amphores de Clazomènes", in Empereur, J.-Y. and Garlan, Y. (eds.), Recherches sur les amphores grecques, BCH Suppl. 13: 461-471. 1986: "Des ateliers d'amphores à Paros et à Naxos", $B C H$ 110: 495-511.

- "1989: "Les régions de production d'amphores impériales en Méditerranée orientale", CEFR 114: 223-248.

Empereur, J.-Y., Hesse, A. and Tuna, N., 1999: "Les Ateliers d'Amphores de Datça, Peninsule de Cnide", in Garlan, Y. (ed.), Production et commerce des amphores anciennes en mer Noire, Aix-en-Provence: 105-115.

Ferrazzoli, A.F., 2010: "Economy of Roman Eastern Rough Cilicia: Some Archaeological Indicators", Bolletino di Archeologia Speciale: 39-50.

Ferrazzoli, A.F. and Ricci, M., 2007: "Elaiussa Sebaste: Produzionie consumi di una città della Cilicia tra V e VII secolo", LRCW 2: 671-688. 
Foley, B.P., DellaPorta, K., Sakellarious, D., Bingham, B.S., Camilli, R., Eustice, R.M., Evagelistis, D., Ferrini, V.L., Katsaros, K., Kourkoumelis, D., Mallios, A., Micha, P., Mindell, D.A., Roman, C., Singh, H., Switzer, D.S. and Theodoulou, T., 2009: "The 2005 Chios Ancient Shipwreck Survey", Hesperia 78: 269-305.

Grace, V.R., 1971: "Samian Amphoras", AJA 40.1: $52-95$.

- 1986: "Premieres remarques sur les amphores de Clazomènes", in Empereur, J.-Y. and Garlan, Y. (eds.), Recherches sur les amphores grecques, BCH Suppl. 13: 461-471.1979: Amphoras and The Ancient Wine Trade, Athens.

Greene, E.S., Leidwanger, J. and Özdaş, H.A., 2011: "Two Early Archaic Shipwrecks at Kekova Adas1 and Kepçe Burnu, Turkey”, IntJNautA 40.1: 60-68.

Gupta, S., Willams, D. and Peacock, D., 2001: "Dressel 2-4 Amphorae and Roman Trade with India: the evidence from Nevasa", South Asian Studies 17.1: 7-18.

Hansson, M.C. and Foley, B.P., 2008: “Ancient DNA Fragments Inside Classical Greek Amphoras reveal Cargo of 2400-year-old shipwreck", JASc 35: 1169-1176.

Hasdağlı, İ., 2012: "The Assessment of the $4^{\text {th }}$ Century B.C. Finds from Three Wells Uncovered at Clazomenae HBT (Hamdi Balaban Tarlas1) Sector", Olba 20: 119-164.

Hayes, J.W., 1992: Excavations at Sarachane in Istanbul, Volume 2: The Pottery, Princeton.

Isler, H.P., 1969: "Heraion von Samos. Eine frühbyzantinische Zisterne", AM 84: 202-230.

Jacobsen, K.W., 2004: "Regional Distribution of Transport Amphorae in Cyprus in the Late roman Period", in Eiring, J. and Lund, J. (eds.), Transport Amphorae and Trade in the Eastern Mediterranean, Acts of the International Colloquium at the Danish Institute at Athens, September 26-29, 2002, Athens: 143-148.

Kac, V.I., Monachov, S.Y., Stolba, V.F. and Sceglov, A.N., 2002: “Tiles and Ceramic Containers", Panskoye I: 101-126.

Kız1l, A., 1986: "Premieres remarques sur les amphores de Clazomènes", in Empereur, J.-Y. and Garlan, Y. (eds.), Recherches sur les amphores grecques, BCH Suppl. 13: 461-471.2008: 2006 Yılı Muğla ili, Milas İlçesi ile Ören ve Selimiye Beldelerinde Arkeolojik Yüzey Araştırmaları", AST 25-3: 357-374. İzmir.

- 2002: Uygarlıkların Başkenti Mylasa ve Çevresi,

-2012: "2010 Y1lı Muğla ili, Milas İlçesi ile Ören ve Selimiye Beldelerinde Arkeolojik Yüzey Araştırmaları”, AST 29-3: 423-438.

K1zıl, A. and Öztekin, I.E., 2009: "2007 Y11 Muğla ili, Milas İlçesi ile Ören ve Selimiye Beldelerinde Arkeolojik Yüzey Araştırmaları", AST 26-3: 293-310.

-2010: "2008 Yılı Muğla ili, Milas İlçesi ile Ören ve Selimiye Beldelerinde Arkeolojik Yüzey Araştırmaları”, AST 27-3: 359-384.

-2011: "2009 Yı1ı Muğla ili, Milas İlçesi ile Ören ve Selimiye Beldelerinde Arkeolojik Yüzey Araştırmaları”, AST 28-1: 401-416.
Karagiorgou, O., 2000: "LRA2: a container from the military annona on the Danubian border?", in Kingsley, S.A. and Decker, M. (eds.), Economy and exchange in the East Mediterranean during Late Antiquity, Oxford: 129-166.

Keay, S.J., 1984: Late Roman amphorae in the Western Mediterranean. A typology and economic study: the Catalan evidence, Oxford.

Lamboglia, N., 1955: "Sulla cronologia delle anfore romane de età republicana", Rivista di studi Liguri 21 : 252-260.

Lang, M., 1976: The Athenian Agora 21. Grafiti and Dipinti, Athens.

Lawall, M.L., 1995: Transport amphoras and trademarks: Imports to Athens and economic diversity in the fifth century B.C., Unpublished $\mathrm{PhD}$ Thesis (The University of Michigan), Michigan.

- 2004: "Archaeological context and Aegean amphora chronologies. A case study of Hellenistic Ephesos", in Eiring, J. and Lund, J. (eds.), Transport Amphorae and trade in the Eastern Mediterranean, Acts of the International Colloquium at the Danish Institute at Athens, September 26-29, 2002, Athens: 171-188.

- 2007: "Hellenistic stamped amphora handles", in Mitsopoulos-Leon, V. and Lang-Auinger, C. (eds.), Die Basilika am Staatsmarkt in Ephesos, 2. Teil. Funde der klassischen bis römischen Zeit, FiE 9, Wien: 28-60.

Leidwanger, J., Greene, E.S. and Tuna, N., 2015: "A Late Antique Ceramic Assemblage at Burgaz, Datça Peninsula, South-West Turkey, and the 'Normality of the Mixed Cargo' in the Ancient Mediterranean", IntJNautA 44.2: 300-311.

Lüdorf, G., 2006: Römische und frühbyzantinische Gebrauchskeramik im Westlichen Kleinasien: Typologie und Chronologie, Rahden.

Majcherek, G., 1995: “Gazan amphorae: Typology reconsidered. Hellenistic and Roman pottery in the eastern Mediterranean", in Meyza, H. and Mlynarczyk, J. (eds.), Advances in scientific studies, Acts of the II Nieborów Pottery Workshop, Warsaw: 163-178.

Mattingly, H.B., 1981: "Coins and amphoras-Chios, Samos and Thasos in the fifth century B.C.", JHS 101: 78-86.

Michaelides, D., 1996: “The Economy of Cyprus during the Hellenistic and Roman periods", in Karageorghis, V. and Michaelides, D. (eds.), The Development of the Cypriot Economy from the Prehistoric Period to the Present Day, Nicosia: 139-52.

Monakhov, S.Iu. and Rogov, E.Ia., 1990: “Amphoras of the Panskoe I Necropolis", AMA 7: 128-153.

Moore, J., 1995: A Survey of the Italian Dressel 2-4 Wine Amphora, Unpublished MA Thesis (McMaster University), Hamilton.

Norskov, V., 2004: "Amphorae from three Wells at the Maussolleion of Halikarnassos: Something to Add to the Typology of Mushroom Rims?", in Eiring, J. and Lund, J. (eds.), Transport Amphorae and Trade in the Eastern Mediterranean, Acts of the International Collo- 
quium at the Danish Institute at Athens, September 2629, 2002, Athens: 285-292.

Opait, A., 2004: Local and Imported Ceramics in the Roman Province of Scythia $\left(4^{\text {th }}-6^{\text {th }}\right.$ centuries AD), Oxford.

- 2007: "From DR 24 to LR 2?", in Bonifay, M. and Tréglia, J.C. (eds.), $L R C W 2$ : 627-642.

Ozanic I., 2005: "Tipovi amfora iz Cibala", VAPD 98: 133-148.

Peacock, D.P.S., 1971: "Roman Amphorae in PreRoman Britain", in Jesson, M. and Hill, D. (eds.), The Iron Age and its Hill Forts. Papers Presented to Sir Mortimer Wheeler, Southampton: 161-188.

- 1984: "Petrology and Origins. The Avenue du Président Habib Bourguiba, Salammbô: The pottery and other ceramic objects from the site", Excavations at Carthage: The British Mission 1-2: 6-28.

Piéri, D., 1998: "Les importations d'amphores orientales en Gaule méridionale durant l'Antiquité tardive et le haut Moyen Age (IVe-VII ${ }^{\mathrm{e}}$ s. apr. J.-C.), Typologie, chronologie et contenu", in Rivet, L. et Saulnier, S., Importations d'amphores en Gaule du Sud, du règne d'Auguste à l'Antiquité tardive, Jun 1998, Istres: 97-106.

- 2005: Le commerce du vin oriental à l'époque byzantine ( $V^{e}-V I I^{e}$ siècles), Beyrouth.

Peacock, D.P.S. and Williams, D.F., 1986: Amphorae and the Roman Economy, London.

Regev, D., 2004: "The Phoenician Transport Amphora", in Eiring, J. and Lund, J. (eds.), Transport Amphorae and Trade in the Eastern Mediterranean, Acts of the International Colloquium at the Danish Institute at Athens, September 26-29, 2002, Athens: 337-352.

Reynolds, P. and Pavlidis, E., 2014: "Nikopolis (Epirus Vetus): an early $7^{\text {th }}$ century pottery assemblage from the 'Bishop's house' (Greece)", $L R C W$ 1-2: 451168.

Riley, J.A., 1979: “The coarse pottery from Berenice. Excavations at Sidi Khrebish Benghazi (Berenice). Vol. II", LibyaAnt Suppl. 5: 91-467.

Saguì, L., 1998: "La ceramica in Italia: secoli VI e VII", in Sagui, L. (ed.), Ceramica in Italia: VI-VII secolo. Atti del Convegno in onore di J.W. Hayes, Roma 11-13 maggio 1995, Firenze: 305-330.

Şenol, A.K., 2015: "Smyrna Kazılarında 2007-2011 Yılları Arasinda Bulunan Ticari Amphoralar", in Ersoy, A. and Şakar, G. (eds.), Smyrna/İzmir Kazı ve Araştırmaları I. Çalıştay Bildirileri, İstanbul: 243-256.

Sealey, P.R., 1985: "Amphoras from the 1970 Excavations at Colchester Sheepen", BARIntSer 142.

Sezgin, Y., 2000: Iskenderiye Kazllarında Ele Geçen Amphoralar Işı̆̆ında Kentin Roma Dönemi Şarap, Zeytinyağl, Salamura Balık ve Sos Ticareti, Unpublished PhD Thesis (Ege University), İzmir.
- 2003: Marmaris Müzesi Ticari Amphoraları, Ankara. - 2004: “Kıbris’ta Amphora Üretimi”, İdol 23: 10-17. - 2008: "Cilician Commercial Relations with Egypt due to the New Evidence of Amphora Finds", Olba 16: 109-132.

- 2009: Arslan Eyce Taşucu Amphora Müzesi'nde Bulunan Ticari Amphoralar ve Akdeniz'de Ticaret İzleri, Silifke.

- 2012: Arkaik Dönem Ionia Üretimi Ticari Amphoralar, Istanbul.

Şenol, A.K., 2015: "New Evidences on the Amphora Production in the Rhodian Peraea during the Early Hellenistic Period", in Lafl, E. and Patac1, S. (eds), Recent Studies on the Archaeology of Anatolia, BAR 2750: 193202.

Şenol, A.K. and Kerem, F., 2000: "İçel Müzesinde Bulunan Bir Grup Amphora", Olba 3: 81-114.

Tchernia, A., 1986: Le vin de l'Italie romaine, Rome. Tekocak, M. and Zoroğlu, K.L., 2013: “Kelenderis'te Bulunan Bir Grup Roma Dönemi Ticari Amphorası ve Düsündürdükleri”, Olba 21: 109-140.

Tzavella, E., Trainor, C. and Maher, M., 2014: "Late Roman Pottery from the Sikyon Survey Project: Local production, imports, and the urban evolution $\left(4^{\text {th }}-7^{\text {th }} \mathrm{c}\right.$. AD) (Greece)", $L R C W$ 4: 91-102.

Varinlioğlu, E., 1981: "Two Inscriptions from Ceramus", ZPE 44: 51-66.

Whitbread, I.K., 1995: Greek Transport Amphorae: a petrological and archaeological study, London.

Williams, D.F., 1990: "A Note on the Petrology of a Samos Cistern Type Amphora from Excavations at the Castello di Udine", AquilNost 61: 281-296.

- 2004: "Dressel 2-4 and the eruption of Vesuvius. Transport Amphorae and Trade in the Eastern Mediterranean", in Eiring, J. and Lund, J. (eds.), Transport Amphorae and Trade in the Eastern Mediterranean, Acts of the International Colloquium at the Danish Institute at Athens, September 26-29, 2002, Athens: 441-450.

Van Doorninck, F.H. Jr., 1989: “The Cargo Amphoras on the Seventh Century Yass1 Ada and the Eleventh Century Serçe Limanı Shipwrecks: Two Examples of a Reuse of Byzantine Amphoras as Transport Jars", in Déroche, V. and Speiser, J.M. (eds.), Recherches sur la céramique byzantine, Actes du colloque EFA-Université de Strasbourg Athènes 8-10 avril 1987, BCH Suppl. 18: 247-57.

Zeest, I.B., 1960: Keramicheskaya Tara Bospora, Moscow.

Zevi, F., 1966: "Appunti sulle anfore romane. La tavola tipologica del Dressel", Archaeologia Classica 18: $208-247$. 